\title{
Nicotiana benthamiana: Its History and Future as a Model for Plant-Pathogen Interactions
}

\author{
Michael M. Goodin, ${ }^{1}$ David Zaitlin, ${ }^{2}$ Rayapati A. Naidu, ${ }^{3}$ and Steven A. Lommel ${ }^{4}$ \\ ${ }^{1}$ Department of Plant Pathology and ${ }^{2}$ Kentucky Tobacco Research and Development Center (KTRDC), University \\ of Kentucky, Lexington 40546, U.S.A.; ${ }^{3}$ Department of Plant Pathology, Irrigated Agriculture Research \& Extension Center, \\ Washington State University, Prosser 99350, U.S.A.; ${ }^{4}$ Department of Plant Pathology, North Carolina State University, \\ Raleigh 27695, U.S.A.
}

Submitted 27 November 2007. Accepted 11 April 2008.

\begin{abstract}
Nicotiana benthamiana is the most widely used experimental host in plant virology, due mainly to the large number of diverse plant viruses that can successfully infect it. Additionally, $N$. benthamiana is susceptible to a wide variety of other plant-pathogenic agents (such as bacteria, oomycetes, fungi, and so on), making this species a cornerstone of host-pathogen research, particularly in the context of innate immunity and defense signaling. Moreover, because it can be genetically transformed and regenerated with good efficiency and is amenable to facile methods for virusinduced gene silencing or transient protein expression, $N$. benthamiana is rapidly gaining popularity in plant biology, particularly in studies requiring protein localization, interaction, or plant-based systems for protein expression and purification. Paradoxically, despite being an indispensable research model, little is known about the origins, genetic variation, or ecology of the $N$. benthamiana accessions currently used by the research community. In addition to addressing these latter topics, the purpose of this review is to provide information regarding sources for tools and reagents that can be used to support research in $N$. benthamiana. Finally, we propose that $N$. benthamiana is well situated to become a premier plant cell biology model, particularly for the virology community, who as a group were the first to recognize the potential of this unique Australian native.
\end{abstract}

Additional keywords: AFLP, agroinfiltration, Arabidopsis, VIGS.

Nicotiana benthamiana: history, taxonomy, and basic biology.

As currently circumscribed, the genus Nicotiana (Solanaceae: Linnaeus 1753) includes 76 species of mainly tropical and subtropical distribution from four continents, with the majority occurring in South America and Australia (Knapp et al. 2004). Although the base haploid chromosome number is considered to be 12 , amphiploidy is common in the genus, with many extant species (or their recent successors) featuring in the reticulate evolution of the allopolyploids. Haploid chromosome num-

Corresponding author: M. Goodin; Telephone: +1.859 .257 .7445 ext. 80725; Fax: +1.859.323.1961; E-mail: mgoodin@uky.edu

* The $\boldsymbol{e}$-Xtra logo stands for "electronic extra" and indicates that supplemental materials documenting detection of TSWV by ELISA and the method used for AFLP analysis are published online. bers range from 9 and 10 (species in section Alatae) to 24 (Nicotiana tabacum and N. rustica) and even 32 in some collections of $N$. suaveolens, and there is a large variation in both chromosome size (Goodspeed 1954) and genome size (Angiosperm DNA C-values database). In his seminal monograph on the genus, Thomas Harper Goodspeed (1954) recognized 13 infrageneric sections, grouping the 61 then-recognized species by common morphological and cytogenetic characters. Modern molecular phylogenetic analyses have largely supported the Goodspeed view of Nicotiana, although the positions of several species have been moved to more correctly reflect their true affinities (Chase et al. 2003; Knapp et al. 2004). These latter authors now recognize 13 sections, with many of the original Goodspeed names preserved.

The subject of this review is $N$. benthamiana Domin, a unique species endemic to Australia. $N$. benthamiana was first discovered and collected on the "N.W. Coast" of New Holland (Australia) by ship's surgeon Benjamin Bynoe on the third voyage of the 10-gun brig HMS Beagle, of Charles Darwin fame. For its final voyage of exploration, the Beagle was commanded by J. C. Wickham (1837 to 1841) and J. Lort Stokes (1841 to 1843), both of whom had sailed with Darwin under Captain Robert FitzRoy. Mr. Bynoe was a highly experienced and valued medical officer and sailor, and he is mentioned many times in Stokes' lengthy two-volume account of this voyage (Stokes 1846). We know that he was also an avid naturalist, having collected with Darwin in the Galapagos and elsewhere on the second Beagle voyage from 1831 to 1836. Bynoe discovered many species new to science, most of which he collected with a rifle (and some of which then were eaten). In between Stokes' excruciatingly detailed accounts of weather, ocean depth, and tides (6 years of observations) are discussions of the native peoples and the flora and fauna encountered on land excursions along the coast and nearby islands. The single reference made to collecting plants came from 7 November 1839, shortly after the discovery of the Victoria River: "Mr. Bynoe, as he had done yesterday, added to his valuable collection a few rare birds, and strange plants;..." (Stokes 1846, volume 2). However, it is not known whether $N$. benthamiana was discovered on that occasion. In a letter to Sir William Hooker, dated 9 October 1843, Bynoe wrote, "I have taken advantage of every opportunity that offered on the Coast of New Holland and indeed the whole collection in Plants, Birds, Shells, Spirit preparations \&c [etc.] were obtained for Sir. Wm. Burnett, however, as there are duplicates of most of them, no doubt I shall be able to contribute towards your Herbarium." (Keevil 
1949). Among the collections donated to the Herbarium Hookerianum are samples of what is now known to science as $N$. benthamiana. Bynoe's original specimen, the holotype, was transferred to the Royal Botanic Gardens, Kew sometime after the death of Sir William Hooker in 1865, and is reproduced as Plate 1 in Burbidge (1960) and here as Figure 1. Written on the original herbarium sheet in an unknown hand is the first classification (the basionym), N. suaveolens var. cordifolia, and the reference to its original publication in Volume IV of the sevenvolume series Flora Australiensis (Bentham 1869). The sheet also bears the mark of Czech botanist and politician Karel Domin, who honored George Bentham with the publication of N. benthamiana as a new taxon in 1929 (Goodspeed 1954).

The 20 Australasian species of Nicotiana all belong to $N$. sect. Suaveolentes and all are of allopolyploid origin. Haploid chromosome numbers within this section can be 16 (32), 18, $19,20,21,22,23$, and 24 , depending on the species. N. benthamiana is one of two species with 19 pairs of chromosomes, the other being $N$. excelsior from central Australia (Burbidge 1960), to which it is closely related (Chase et al. 2003). The size of the haploid genome (1 C-value) of $N$. benthamiana is estimated to be $3.2 \mathrm{pg}(=3,136 \mathrm{Mbp})$ (Bennett and Leitch 1995; Narayan 1987). In contrast, the Arabidopsis thaliana genome is $157 \mathrm{Mbp}$, nearly 20-fold smaller than that of $N$. benthamiana (Bennett and Leitch 2005; Bennett et al. 2003).

$N$. benthamiana has a broad, somewhat discontinuous distribution from extreme Western Australia east to western Queens- land, with a single documented collection from northern South Australia (for a map see Australia's Virtual Herbarium website). In her examination of both living and preserved specimens, Burbidge (1960) observed that, "A considerable range of variation is at present accepted under this name [although the] differences between specimens are in part due to whether the plants were collected in a juvenile, mature or secondary regrowth state as well as to differences between populations" (page 351). Like the desert tobacco (N. obtusifolia) of North America, $N$. benthamiana is distributed widely and occupies seasonally arid habitats that are unfavorable to other native species of Nicotiana. Because of this, and because N. benthamiana is considered to have evolved in isolation from the other Australian species in the genus (Goodspeed 1954), we would expect to find considerable morphological, physiological, genetic, and genomic diversity present in natural populations of this species. Partial support for this hypothesis comes from field notes accompanying $N$. benthamiana herbarium specimens collected from 1994 to 2004 (Nicholas S. Lander, Western Australia Herbarium, personal communication). Collections of the species made in Western Australia from $15^{\circ} 16^{\prime}$ to $25^{\circ} 30^{\prime} \mathrm{S}$ and $115^{\circ} 29^{\prime}$ to $128^{\circ} 41^{\prime} \mathrm{E}$, a land area of approximately 300,000 square miles (approximately $777,000 \mathrm{~km}^{2}$ ), are recorded to vary in plant size, plant form, flower color, flower scent, habitat preference, soil type, and floristic association.

$N$. benthamiana has become an extremely important subject for the study of host-pathogen interactions, particularly those
A

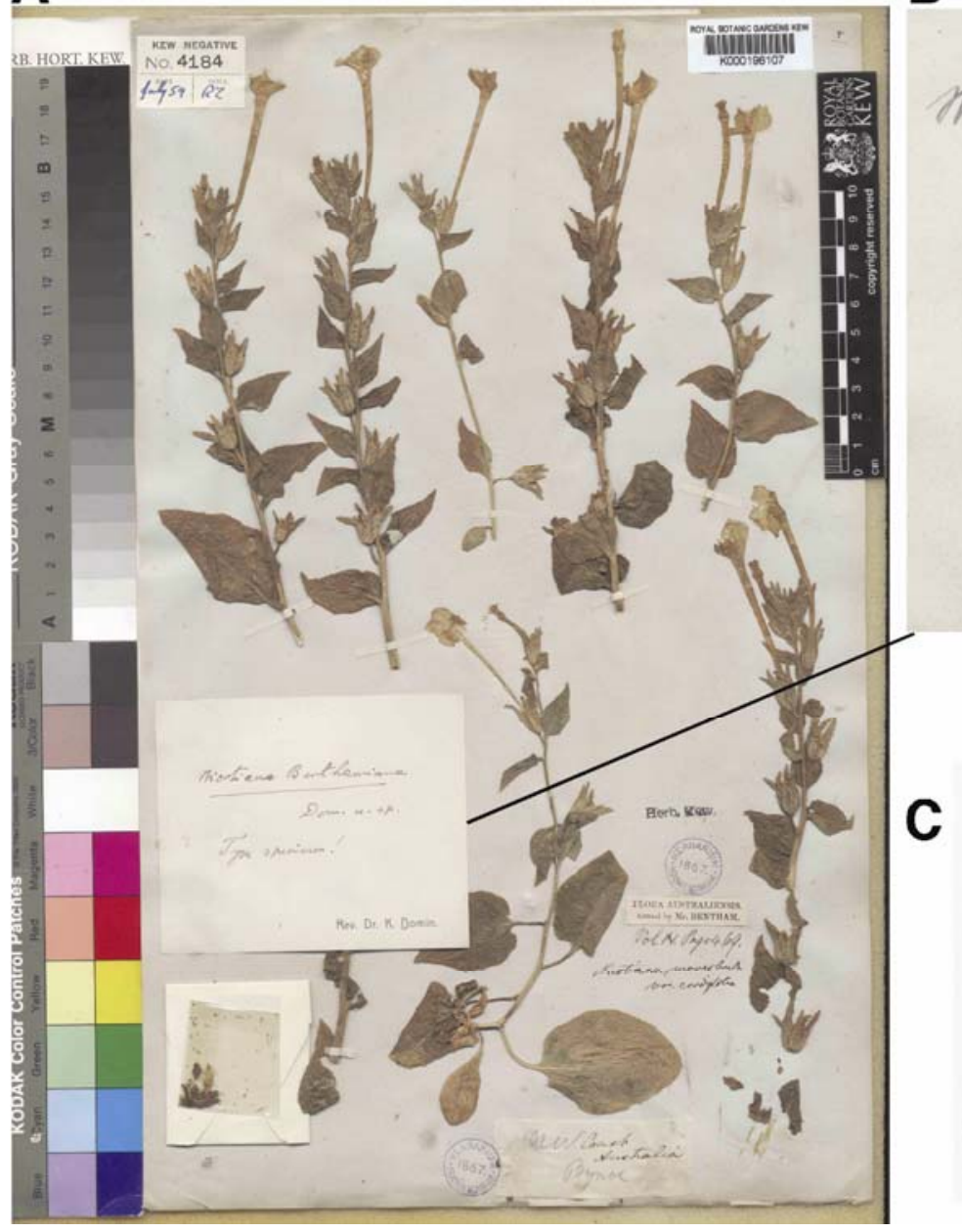

B
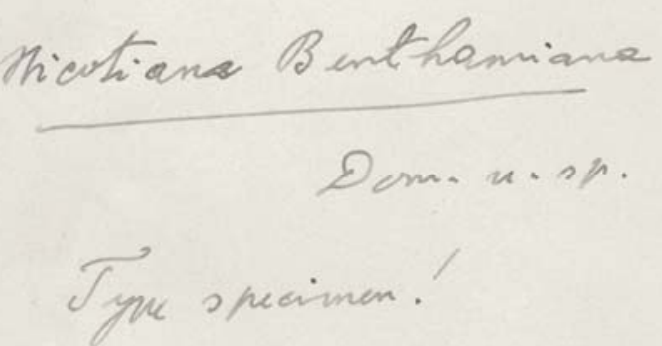

Fig. 1. A, Color image of the original herbarium sheet bearing the type specimen of Nicotiana benthamiana, collected by Benjamin Bynoe and housed at the Royal Botanic Gardens, Kew. Note the flowers, which average approximately $5 \mathrm{~cm}$ in length. B, Detail from A showing an attached handwritten note by Karel Domin designating these plants as the type specimen. C, Photograph of Karel Domin. 
involving plant viruses. A search of the PubMed database (through November 2006) finds 1,743 citations containing the term "nicotiana benthamiana" since 1995, with 38\% (667) having accumulated in 2006 alone (Fig. 2). Examination of the titles reveals the fact that most of these articles are concerned with studies of viral or bacterial phytopathology or gene silencing. Given this statistic, it is quite surprising that so little is known about the basic genetics or genomics and phylogeography of this important plant. As stated earlier, $N$. benthamiana was first collected $>160$ years ago, but there are scant records of its repeated collection from the wild (three are mentioned by Goodspeed) (1954, page 487). A survey of accessible online seed and gene banks reveals the paucity of publicly available genetic resources for this species: the United States Department of Agriculture-Agricultural Research Service (USDA-ARS) National Plant Germplasm System has two accessions (plant introduction [PI] numbers 555478 and 555684), the Botanical Garden of Nijmegen (Netherlands) lists two accessions, the Institut fur Pflanzengenetik und Kulturpflanzenforschung Gatersleben (IPK, Germany) has one, and the Australian Plant Genetic Resource Information Service (AusPGRIS) lists five accessions (all donated by D. D. Wark) but only two are presently available for distribution. With the exception of the three unavailable Australian accessions, none of these come with any documentation or provenance. The Kentucky Tobacco Research and Development Center (KTRDC) at the University of Kentucky presently maintains six accessions of $N$. benthamiana, of which two are the USDA-ARS accessions and another two are almost certainly redundant. N. Burbidge obtained seed from the wild and grew several of these collections in order to compare them with the type (Bynoe) specimen (Burbidge 1960). Two of these (T.S. 139 and T.S. 318) are listed as unavailable by AusPGRIS, and the disposition of the other Burbidge material is unknown. Based on plant morphology and the pattern of reticulation of the seed testa, she concluded that accession T.S. 299, from near the Ord River (Kimberley region, Western Australia), was "nearest to the type" (Burbidge 1960). This is highly unlikely, however; an account of the exploration of Western Australia (Battye 1924) reveals that the Ord River was not discovered until 1879, more than 30 years after the Beagle returned to Portsmouth on 30 September 1843 and almost 15 years after Bynoe's death in 1865 at the age of 61 (Keevil 1949).

As with accounts regarding its collection, records that could shed light on how accessions of $N$. benthamiana made their way into the research community are equally scant. It is most likely that $N$. benthamiana was adopted as a model plant primarily due to its unparalleled susceptibility to viruses, many of which do not infect A. thaliana (Christie and Crawford 1978; Coutts and Buck 1985; Quacquarelli 1975). This susceptibility is often considered to be a general characteristic of $N$. benthamiana as a species. However, as we demonstrate in a later section, this view is likely to be naive because there is quite possibly only a single accession of $N$. benthamiana, or a collection of closely related accessions, being used by the plant research community today. From preliminary experiments with a previously uncharacterized accession from the USDA Tobacco Collection, it appears that there could be significant variation in susceptibility to virus infection within this species. Thus, there is a compelling need for collection and characterization of new accessions of $N$. benthamiana from its natural range in northwestern Australia in order to expand the genetic diversity available to researchers worldwide. That said, despite widespread ignorance of the provenance of the accessions currently in use, the genetic uniformity of these plants has potentially contributed positively to the rapid increase in research conducted with this species. Tools and resources to support pro- jects with $N$. benthamiana can be readily exchanged and used across laboratories, in many cases without the need to consider plant effects other than those influenced by environmental and growth conditions (Fig. 2).

\section{Distance-based phenetic analysis of $N$. benthamiana.}

In addition to documenting the history of $N$. benthamiana, we are also concerned with establishing standards for defining accessions of this species. To this end, all of our transgenic lines (Chakrabarty et al. 2007; Goodin et al. 2007a) have been produced with the same accession used to develop the widely utilized '16c' line, which expresses GFP targeted, and which has been instrumental in the identification and characterization of suppressors of RNA silencing and related research (Brigneti et al. 1998; Cao et al. 2005; Roth et al. 2004; Ruiz et al. 1998; Segers et al. 2006). Our decision to use the 16c parental line was made primarily to avoid the possibility of producing transgenic plants with a significantly to the endoplasmic reticulum (ER) different genetic background. However, this begged the question of how much genetic variation actually exists among the $N$. benthamiana accessions being used by the research community. An informal e-mail survey, conducted by us in 2005, canvassed 236 plant virologists to obtain information about the research use of this species. This survey failed to identify the number of accessions in use or how $N$. benthamiana came to be adopted by the research community. Although some virologists were familiar with early papers dealing with $N$. benthamiana as a research model, it could not be established where the actual accessions now in use were collected, in whose laboratory they were first used, or the order of distribution of this species among researchers. Therefore, we conducted an amplified fragment length polymorphism (AFLP)-based cluster analysis in an attempt to determine whether any genetic variation existed among research accessions. We used DNA obtained from plants grown from seed submitted by researchers in five countries (Supplementary Data 1). When grown to maturity, no obvious differences in growth habit, foliage, or flowers were noted. However, a novel accession of $N$. benthamiana in the KTRDC collection was a much larger, coarser plant with larger flowers than the research accessions. This same accession (USDA PI no. 555684), here

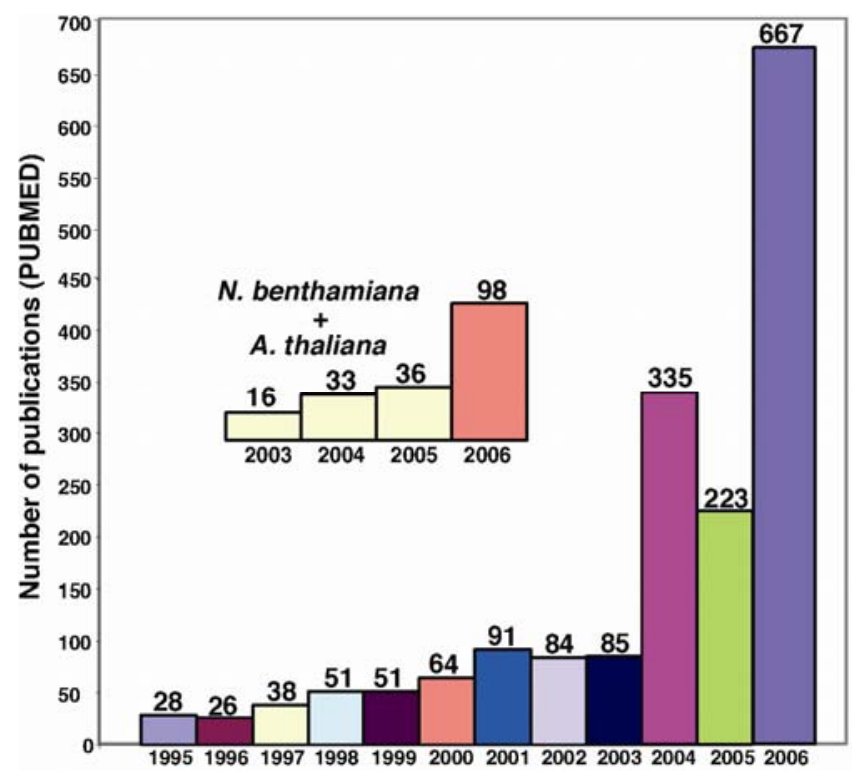

Fig. 2. Rapid increase in the number of research publications using Nicotiana benthamiana. Data were obtained from the PUBMED database on the search term "nicotiana benthamiana". 
referred to as 'KTRDC-4', stood alone in the AFLP cluster analysis (Fig. 3). Pairwise comparisons between it and 10 other accessions (5 from KTRDC and 5 survey submissions) gave similarity coefficients (Jaccard 1908; Lara-Cabrera and Spooner 2004) that averaged 0.404. Comparisons among the other 10 accessions averaged 0.924 , indicating that they are very closely related and could possibly be derived from one source. To put this into perspective, similarity coefficients calculated between the 11 accessions of $N$. benthamiana and an accession of $N$. excelsior, the only other $n=19$ species from Australia, averaged 0.359 (Fig 3A). Interestingly, all accessions of $N$. benthamiana submitted by researchers had the smallflower phenotype, whereas KTRDC-4 had large flowers, a characteristic it shares with the type specimen (Fig. 1A and B).

\section{Variation in susceptibility to virus infection in $N$. benthamiana ecotypes.}

Given the gross morphological variation between the largeand small-flowered plants, we hypothesized that they may also differ in their susceptibility to pathogens. Our initial experiments suggest that KTRDC-4 was significantly more resistant to infection by Tomato spotted wilt virus (Fig. 4; Supplementary Materials 1) and other viruses (data not shown), than was the 'standard' accession of $N$. benthamiana. These data are particularly intriguing because $N$. benthamiana is generally considered to be almost universally susceptible to plant viruses. This opinion is clearly biased given the genetic uniformity among accessions used for research and the absence of any data in which variation in resistance among accessions has been addressed, as has been done for A. thaliana (Callaway et al. 1996; Martin et al. 1999).

The above comparison raises a question that has long been of interest to plant virologists; namely, why is $N$. benthamiana seemingly susceptible to the majority of plant viruses? To address this issue, Yang and associates (2004) determined that the near universal virus susceptibility is, at least in part, linked

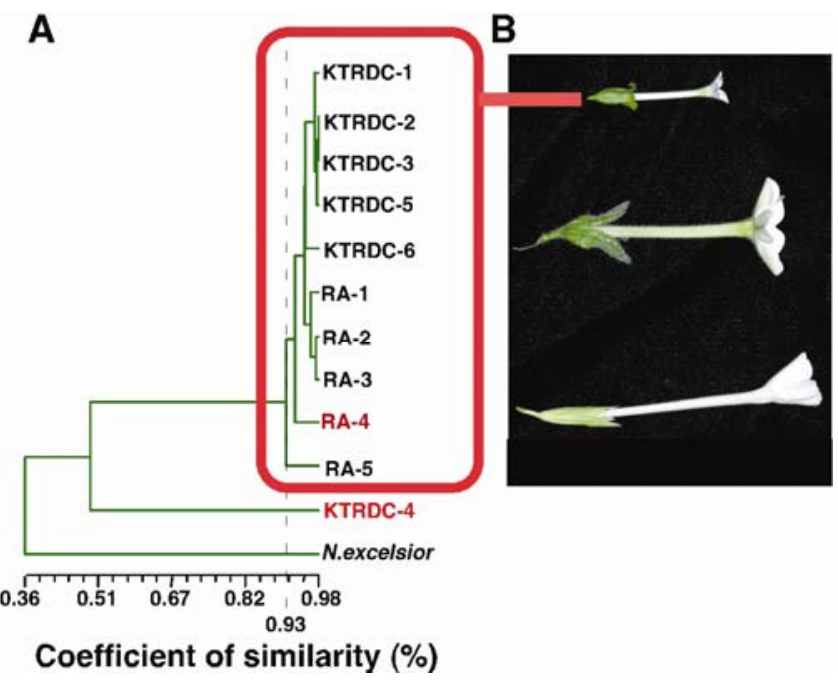

Fig. 3. A, Phenetic relationships among 11 accessions of Nicotiana benthamiana based upon amplified fragment length polymorphism cluster analyses. Five research accessions (RAs) were submitted by laboratories in Spain (RA-2), the United Kingdom (RA-4), and the United States (RA-1, RA-3, and RA-5). Six accessions were from the collection of the Kentucky Tobacco Research and Development Center (KTRDC). N. excelsior was included in these analyses because it is the only other $n=19$ Nicotiana $\mathrm{sp}$. from Australia. B, Examples of floral phenotypes from plants included in this study. All RAs had a small flower phenotype (top). KTRDC-4 had large flowers reminiscent of the type specimen (middle). The limb on some flowers of $N$. excelsior (bottom) never fully expand, unlike those of N. benthamiana. to a naturally occurring mutation in an RNA-dependent RNA polymerase gene $(N b R d R P 1 m)$ present in the $N$. benthamiana genome. Enhanced virus resistance is conferred to plants expressing the corresponding gene from Medicago truncatula. However, in the absence of a diverse representative collection of $N$. benthamiana accessions, it cannot be ruled out that this species is universally susceptible to viruses given that
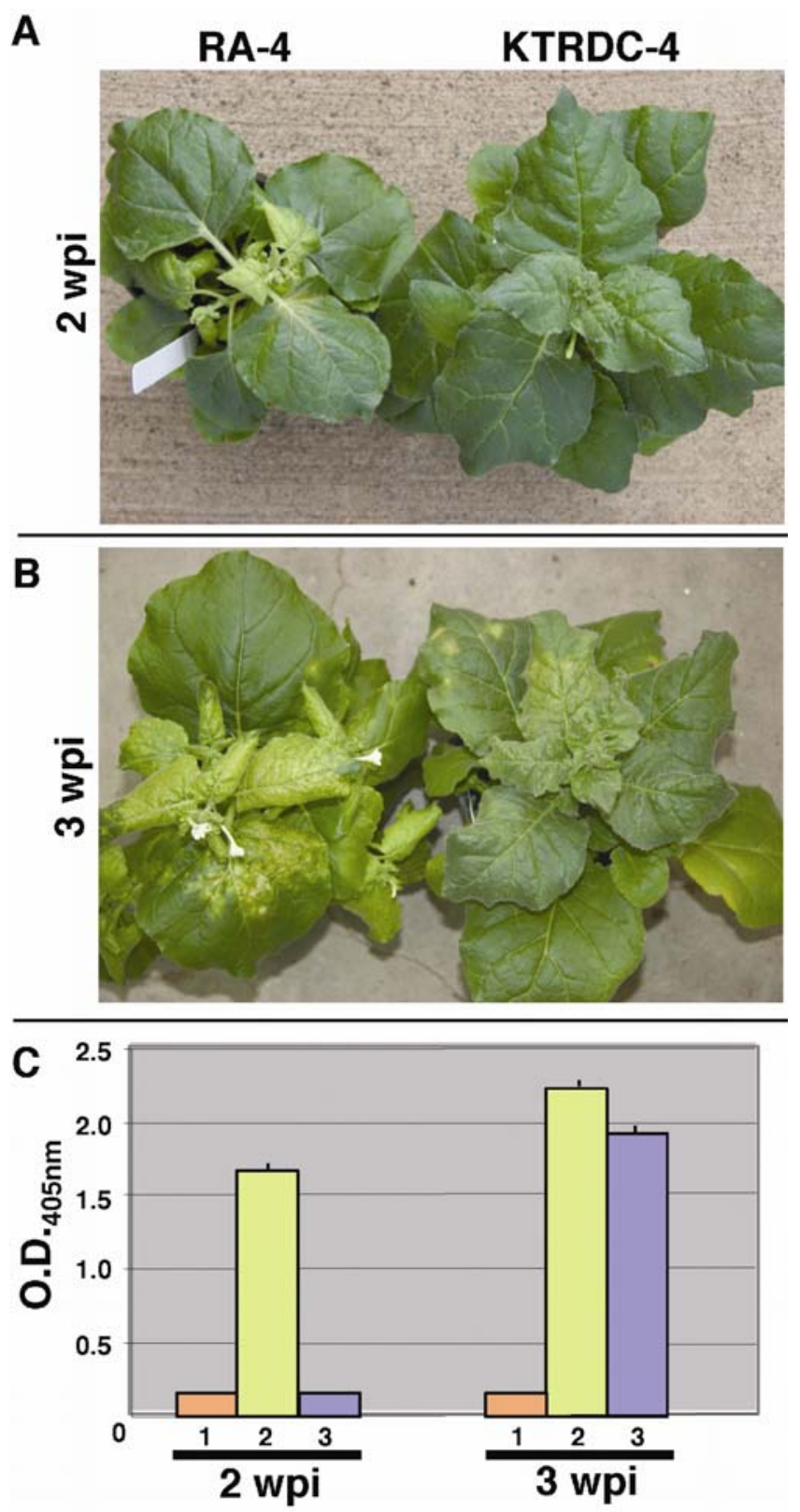

Fig. 4. A through C, Mature plants of the research accession(RA-4) and Kentucky Tobacco Research and Development Center (KTRDC-4) accessions show differential susceptibility to infection by Tomato spotted wilt virus (TSWV)-T. A, Visible symptoms of leaf chlorosis are observed only on RA-4 2 weeks post inoculation (wpi). B, Symptoms on plants at 3 wpi. Symptoms are more severe on RA-4 when compared with those produced in KTRDC-4. Both types of plants show mortality by 6 and 10 wpi, respectively (data not shown). C, Enzyme-linked immunosorbent assay data show that virus was detected in symptomatic leaves of RA-4 but not in KTRDC-4 at 2 wpi (shown in A), whereas virus was detected in symptomatic leaves of both RA-4 and KTRDC-4 at 3 wpi (shown in B). The results indicate low levels of replication or delayed systemic spread of virus in KTRDC-4. 1 = Mock inoculated RA-4, 2 = TSWV-inoculated RA-4, 3 = TSWV-inoculated KTRDC-4, and O.D. = optical density at $405 \mathrm{~nm}$. Tissue samples were pooled from six inoculated plants at each time point. The experiments were repeated three times. 
KTRDC-4 appears to have enhanced resistance compared with the widely used research accession, which differs so much from the type (Bynoe) specimen. Therefore, it is clear that a significant effort must be made to collect and characterize novel accessions of $N$. benthamiana in order to resolve issues about its susceptibility to viruses and, more importantly, to provide a collection of genetically diverse ecotypes, which is essential for any legitimate model system.

\section{The rise of $N$. benthamiana.}

Despite its early adoption by the plant virology community, $N$. benthamiana did not enter the wider arena of plant biology until the advent of three major technical advances. First was the ability to express foreign genes from a plant virus vector. This technology not only provided a means to track viral movement in living cells but also revealed new insights into fundamental aspects of plant biology such as plasmodesmatal gating and macromolecular movement between cells, and also allowed definition of the proteins targeted to them (Chapman et al. 1992; Cruz et al. 1996; Escobar et al. 2003; Lucas 2006).

Second, the development of plant virus-based vectors quickly led to the invention of a technology now known as virus-induced gene silencing (VIGS) (Kumagai et al. 1995; Thomas et al. 2001). VIGS enabled directed, systemic downregulation of virtually any gene-of-interest in plants, thereby transforming $N$. benthamiana into a powerful reverse-genetics system (Dong et al. 2007; Fu et al. 2005; Liu et al. 2002; Ratcliff et al. 2001). One of the great advantages of VIGS is its ability to reduce the effects of genetic redundancy if the cDNA used for silencing is homologous to more than a single member of a multiple gene family. Alternatively, by prudent selection of cDNAs to be used for VIGS, either individual or multiple members of a gene family can be targeted (Burch-Smith et al. 2004). Interestingly, for many years the viral vectors used for VIGS were particularly well suited for use in $N$. benthamiana and had little utility in A. thaliana, the flagship of plant molecular genetics although, more recently, this limitation has eased (Burch-Smith et al. 2006; Deleris et al. 2006). Plant viral vectors, RNA silencing, and VIGS have all been the subjects of excellent reviews published recently; therefore, we direct readers to these articles for elaboration on these topics (BurchSmith et al. 2004; Ding and Voinnet 2007; Earley et al. 2006; Robertson 2004).

The third technology that served to popularize $N$. benthamiana as a research model was agroinfiltration, which permits proteins of interest, often expressed as fusions to autofluorescent proteins, to be produced transiently in plant cells in a straightforward manner that is particularly well suited to highthroughput studies (Fig. 5) (Goodin et al. 2002; Schob et al. 1997; Voinnet et al. 2003). Methodologically, agroinfiltration may at first glance seem too simple to be useful, but it is presently the most facile means to transiently express proteins in plant cells. Briefly, a suspension of Agrobacterium tumefaciens cells carrying binary plasmid vectors designed for protein expression is infiltrated into the intercellular space within a leaf using nothing more sophisticated than a 1-ml disposable syringe (sans needle). After approximately 24 to $48 \mathrm{~h}$ of incubation, sections of infiltrated leaves can be sampled for microscopy or biochemical analyses. Interestingly, as for VIGS, agroinfiltration works exceptionally well in $N$. benthamiana but poorly in other plants, including Arabidopsis thaliana. Thus, the three major advances for manipulating protein and gene expression in plant cells are best suited to $N$. benthamiana. Taken together, it is not surprising that, in addition to the increase in research publications in which $N$. benthamiana was the sole model plant used, there has been a parallel increase in the use of this species to compliment studies initiated in $A$. thaliana (Fig. 2, inset) (Heese et al. 2007; Ohad et al. 2007; Strasser et al. 2007; Thomas et al. 2008), wheat (Tardif et al. 2007), and other plants (Gabriëls et al. 2007; Messinese et al. 2007; Xiao et al. 2007).

The further utility of $N$. benthamiana is underscored by studies that combine the methods described above. For example, agroinfiltration and VIGS have been used simultaneously to investigate signal transduction (Gabriëls et al. 2006) and protein trafficking (Kanneganti et al. 2007).

By taking advantage of fact that elevated temperatures $\left(33^{\circ} \mathrm{C}\right)$ prevent the hypersensitive response (HR) in transgenic tomato plants co-expressing the $C f-4$ resistance gene and the cognate HR-inducing gene Avr4, Gabriëls and associates (2006) were able to synchronize the appearance of HR in plants when the temperature was reduced to $25^{\circ} \mathrm{C}$. They then used AFLP analyses to identify 442 mRNA transcripts that were differentially expressed in the early stages of the HR. VIGS was then used to silence some of these transcripts in $N$. benthamiana. This is a legitimate approach given the extensive homology between cDNAs of Solanaceous species (Liu et al. 2002; Rensink et al. 2005). Following the onset of VIGS, agroinfiltation was used to co-express avirulence proteins in $C f-4$ tranasgenic $N$. benthamiana leaves. Using this combined approach, a heat-shock protein, a nuclear GTPase, an L19 ribosomal protein, and, most interestingly, a nucleotide-binding leucine-rich repeat (NB-LRR)-type protein were implicated in HR induction.

In a related approach, Kanneganti and associates (2007) used VIGS to silence importin- $\alpha$ homologues in $N$. benthamiana. This resulted in plants that could be used to characterize the nuclear localization of yellow fluorescent protein fusions that were expressed in leaves by agroinfiltration (Kanneganti et al. 2007). Taken together, these and similar studies exemplify the rapidity with which $N$. benthamiana can be manipulated in a manner that is, by and large, without equal in plant biology. It is beyond the scope of this article to describe the

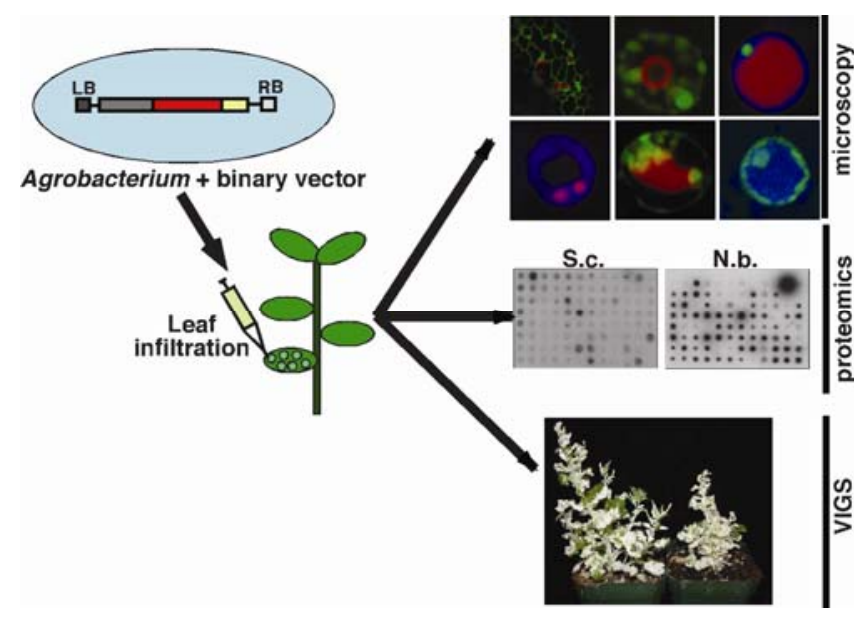

Fig. 5. Agroinfiltration can be used for a variety of purposes. Suspensions of Agrobacterium tumefaciens cells transformed with a binary vector for expression of genes of interest are infiltrated into Nicotiana benthamiana leaves (Note; only the portion between the left [LB] and right [RB] borders of a generic binary vector is shown). Depending on the particular study, these plants may be either wild-type or expressing a transgene; for example, fluorescent markers for the endoplasmic reticulum, nucleolus (Fib1), or chromatin (H2B). For microscopy and biochemical studies, leaf tissues are typically sampled within 24 to $94 \mathrm{~h}$ post infiltration. For virusinduced gene silencing (VIGS), plants may be incubated for several weeks until the gene of interest is silenced, such as the knockdown of the phytoene desaturase gene resulting in the bleached leaf phenotype shown here. Micrographs are reprinted from Goodin and associates (2007a,b). The protein arrays are reprinted from Burch-Smith and associates (2007). 
many variants of VIGS vectors, agroinfiltration methods, or the combinations in which these tools have been applied. However, it suffices to say that advances continue to be made both with respect to novel vector systems as well as their use alone or in combination with other techniques (Chakrabarty et al. 2007; Dong et al. 2007; Kamoun et al. 2003; Lindbo 2007; Liu and Page 2008; Robertson 2004; Ryu et al. 2004).

\section{N. benthamiana: second fiddle or virtuoso?}

The importance of $N$. benthamiana as an indispensable research model in plant virology is underscored by its role in seminal findings that have been the subject of several recent reviews (Bisaro 2006; Briddon and Stanley 2006; Dreher and Miller 2006; Lucas 2006; Nagy and Pogany 2006). Recently, $N$. benthamiana proved instrumental in demonstrating that host factors required for replication of Tombusvirus spp., identified in a yeast model are also required by these viruses in plants (Wang and Nagy 2008). Briefly, these authors demonstrated that, in yeast cells, Tomato bushy stunt virus (TBSV), a plus-stranded RNA virus, incorporates the host metabolic enzyme glyceraldehyde-3-phosphate dehydrogenase (GAPDH) into the viral replicase complex. Using Tobacco rattle virus (TRV)-mediated VIGS, the authors further demonstrated that downregulation of GAPDH in $N$. benthamiana decreased replication of TBSV but not the distantly related Tobacco mosaic virus (Wang and Nagy 2008). Interestingly, A. thaliana is a nonhost for TBSV, making the development of $N$. benthamiana as a research model essential for advancing the groundbreaking research established in yeast (Panavas et al. 2008).

But how does $N$. benthamiana feature into the larger context of plant biology? With the rapid increase in the number of sequenced plant genomes, we posit that a common plant model for advancing the derivative functional and systems biology analyses is essential. In Table 1, and in brief descriptions below, we identify some of the necessary resources available to support research with $N$. benthamiana, which we fully expect to play a major role in the post-genomics era.

Vectors for expression of autofluorescent protein fusions. At present, $N$. benthamiana is the most tractable plant system for conducting high-throughput protein localization studies, given the ease of agroinfiltration and the ability to counter-stain tissues with dyes for labeling nuclei, endomembranes, and other relevant structures within cells (Goodin et al. 2005, 2007a). In addition to facilitating acquisition of higher quality micrographs, agroinfiltration permits large numbers (hundreds to thousands) of cells to be transfected simultaneously. This not only increases confidence that micrographs are correctly representative of the true localization patterns but also that the data can be readily quantified. Additionally, sufficient tissue can be infiltrated to permit small-scale protein purification or other analyses on the same tissue used for microscopy. Although any appropriately constructed binary vector can be used for agroinfiltration, the most recently described improved systems rely upon Gateway or other ligation-independent cloning technolo-

Table 1. Resources for research conducted in Nicotiana benthamiana ${ }^{\mathrm{a}}$

\begin{tabular}{|c|c|c|c|c|c|c|c|c|c|}
\hline $\begin{array}{l}\text { Principle investigator, } \\
\text { URL or e-mail }\end{array}$ & $\begin{array}{l}\text { Viral exp. } \\
\text { vector }\end{array}$ & $\begin{array}{l}\text { VIGS } \\
\text { vector }\end{array}$ & $\begin{array}{l}\text { Binary } \\
\text { vectors }\end{array}$ & $\begin{array}{l}\text { Expression } \\
\text { cassettes }\end{array}$ & $\begin{array}{l}\text { Transgenic } \\
\text { plants }\end{array}$ & $\begin{array}{c}\text { cDNA } \\
\text { library }\end{array}$ & $\begin{array}{l}\text { Two-hybrid } \\
\text { library }\end{array}$ & EST & Other \\
\hline $\begin{array}{l}\text { Baulcombe } \\
\text { http://www.plantsci.cam.ac.uk/research/ } \\
\text { davidbaulcombe.html }\end{array}$ & PVX & TRV & $\ldots$ & $\begin{array}{l}\text { RNA } \\
\text { silencing } \\
\text { suppressors }\end{array}$ & $16 \mathrm{c}$ & $\ldots$ & $\ldots$ & $\ldots$ & $\ldots$ \\
\hline $\begin{array}{l}\text { Gelvin Lab } \\
\text { http://www.biology.purdue.edu/people/ } \\
\text { faculty/gelvin/nsf/ }\end{array}$ & $\ldots$ & $\ldots$ & $\begin{array}{l}\text { pSAT } \\
\text { (BiFC) }\end{array}$ & $\ldots$ & $\ldots$ & $\ldots$ & $\ldots$ & $\ldots$ & $\ldots$ \\
\hline $\begin{array}{l}\text { Dinesh-Kumar Lab } \\
\text { http://plantfunctionalgenomics.yale.edu/ } \\
\text { research/library.html }\end{array}$ & $\ldots$ & TRV & $\ldots$ & $\begin{array}{l}R \text { gene } \\
\text { signaling }\end{array}$ & $\ldots$ & $\mathrm{Nb}, \mathrm{Sl}$ & $\ldots$ & $\cdots$ & $\begin{array}{l}\text { Arabidopsis } \\
\text { protein array }\end{array}$ \\
\hline $\begin{array}{l}\text { Lommel Lab } \\
\text { http://www.cals.ncsu.edu/plantpath/ } \\
\text { people/faculty/lommel/ }\end{array}$ & $\ldots$ & $\ldots$ & $\ldots$ & $\ldots$ & $\ldots$ & $\ldots$ & $\ldots$ & $\ldots$ & $\mathrm{Nb}$ microarray \\
\hline Kim Lab kookkim@snu.ac.kr & $\ldots$ & $\ldots$ & $\cdots$ & $\ldots$ & $\ldots$ & $\ldots$ & $\mathrm{X}$ & $\ldots$ & $\cdots$ \\
\hline $\begin{array}{l}\text { Goodin Lab } \\
\text { http://www.ca.uky.edu/agcollege/ } \\
\text { plantpathology/goodin/index.htm }\end{array}$ & $\ldots$ & $\ldots$ & $\begin{array}{l}\text { pGD } \\
\text { pSITE }\end{array}$ & Cellular loci & $\begin{array}{l}\text { Marker } \\
\text { lines }\end{array}$ & $\ldots$ & $\ldots$ & $\ldots$ & $\ldots$ \\
\hline $\begin{array}{l}\text { Page Lab } \\
\text { http://www.pbi.nrc.ca/en/research/ } \\
\text { ropage/page.htm }\end{array}$ & $\ldots$ & $\begin{array}{l}\text { TRV } \\
\text { der. }\end{array}$ & $\ldots$ & $\ldots$ & $\ldots$ & $\mathrm{Nb}$ & $\ldots$ & $\ldots$ & $\ldots$ \\
\hline $\begin{array}{l}\text { Sunter Lab } \\
\text { http://www.bio.utsa.edu/faculty/ } \\
\text { sunter.html }\end{array}$ & $\ldots$ & $\ldots$ & $\ldots$ & $\ldots$ & $\ldots$ & $\ldots$ & $\ldots$ & $\ldots$ & $\begin{array}{l}\text { Nb suspension } \\
\text { cell line }\end{array}$ \\
\hline $\begin{array}{l}\text { Tzfira Lab } \\
\text { http://www.biology.lsa.umich.edu/ } \\
\text { research/labs/ttzfira/ }\end{array}$ & $\ldots$ & $\ldots$ & pSAT & $\ldots$ & $\ldots$ & $\ldots$ & $\ldots$ & $\ldots$ & $\ldots$ \\
\hline $\begin{array}{l}\text { Kentucky Tobacco Research \& } \\
\text { Development Center (KTRDC) } \\
\text { http://www.uky.edu/KTRDC/ }\end{array}$ & $\ldots$ & $\ldots$ & $\ldots$ & $\ldots$ & $\ldots$ & $\ldots$ & $\ldots$ & $\ldots$ & Seed \\
\hline $\begin{array}{l}\text { Boyce Thompson Institute } \\
\text { http://bti.cornell.edu/CGEP/CGEP.html } \\
\text { The Institute for Genomic Research }\end{array}$ & $\ldots$ & $\ldots$ & $\ldots$ & $\ldots$ & $\ldots$ & $\ldots$ & $\ldots$ & $\ldots$ & $\begin{array}{l}\text { Tomato EST } \\
\text { microarray }\end{array}$ \\
\hline $\begin{array}{l}\text { http://www.tigr.org/tigr- } \\
\text { scripts/tdb/sol/sol_gen_facts.pl }\end{array}$ & $\ldots$ & $\ldots$ & $\ldots$ & $\ldots$ & $\ldots$ & $\ldots$ & $\ldots$ & $\mathrm{X}$ & $\begin{array}{l}\text { Potato EST } \\
\text { microarray }\end{array}$ \\
\hline $\begin{array}{l}\text { The Tobacco Genome Initiative } \\
\text { http://www.tobaccogenome.org/ }\end{array}$ & $\ldots$ & $\ldots$ & $\ldots$ & $\ldots$ & $\ldots$ & $\ldots$ & $\ldots$ & $\mathrm{X}$ & $\begin{array}{l}\mathrm{Nb} \text { oligo } \\
\text { microarray }\end{array}$ \\
\hline
\end{tabular}

${ }^{a}$ VIGS = virus-induced gene silencing, $\mathrm{EST}=$ expressed sequence tag sequence, $\mathrm{PVX}=$ Potato virus $X, \mathrm{TRV}=$ Tobacco rattle virus, $\mathrm{BiFC}=$ bimolecular fluorescence complementation, $\mathrm{Nb}=N$. benthamiana, $\mathrm{Sl}=$ Solanum lycopersicum (tomato), $\mathrm{TRV}$ der. $=\mathrm{TRV}$ derivatives. 
gies (Chakrabarty et al. 2007; Dong et al. 2007; Earley et al. 2006; Karimi et al. 2007). Continued improvements in expression vectors, autofluorescent proteins, and imaging technologies (Goodin et al. 2007b) suggest that $N$. benthamiana will play a significant role in the task of localizing plant proteomes, as has been done for other essential research models (Laketa et al. 2007; Pepperkok and Ellenberg 2006; Simpson and Pepperkok 2006). Importantly, it has been our experience that protein localization via agroinfiltration generally parallels that observed in the context of stable transformation (Goodin et al. 2007a). Therefore, this favors transient expression for large-scale localization projects, which can then be followed by smaller, more directed studies using transgenic plants if necessary.

Construction of protein interaction maps. In addition to being an exceptional system for protein localization in plant cells, $N$. benthamiana has been instrumental as a platform for protein-protein interaction studies, particularly with respect to characterization of the proteome of Arabidopsis and other species (Citovsky et al. 2006; Ohad et al. 2007; Popescu et al. 2007; Tardif et al. 2007). In a recent review of the method, Ohad and associates (2007) provided a table describing examples where bimolecular fluorescence complementation (BiFC) was used to study protein interactions and localization in plant cells. Of the 40 examples given, $N$. benthamiana was, by far, the most frequently employed of the six different plant species used for conducting BiFC experiments. Interestingly, of the 25 examples where Arabidopsis proteins were characterized, heterologous expression systems were used in all cases except five, again with $N$. benthamiana serving as the predominant plant for BiFC analyses.

In addition to BiFC and other protein localization studies, the large leaves of $N$. benthamiana make it convenient for use in situations where proteins of interest need to be purified in yields sufficient to support proteomics and biochemical studies (Popescu et al. 2007) (Fig. 5). Most recently, in order to identify targets on an A. thaliana protein array containing 1,133 proteins, calmodulin-related proteins used to probe the array were first purified from $N$. benthamiana following agroinfiltration. The proteins expressed in $N$. benthamiana proved to be superior to probes purified from yeast cells, particularly with respect to the autophosphorylation activities of 96 protein kinases (Fig. 5). These and similar plant proteomics studies should greatly benefit from the recent development of "launch vectors" that express replicons derived from Tobacco mosaic virus, into which transgenes of interest are cloned that, in turn, are introduced into plant cells via agroinfiltation (Lindbo 2007; Musiychuk et al. 2007).

Microarrays. Currently, at least four array platforms suitable for RNA profiling in $N$. benthamiana are available. These include the Tom1 (cDNA) and Tom2 (oligonucleotide) arrays that are derived from tomato expressed sequence tag (EST) data and which have been used for profiling RNA from a number of different Solanaceous species (Moore et al. 2005). Additionally, cDNA arrays derived from potato EST have been used for profiling $N$. benthamiana RNA to determine changes in gene expression in response to virus infection (Dardick 2007; Senthil et al. 2005). Most recently, in collaboration with NimbleGen (Madison, WI, U.S.A.), S. Lommel and colleagues have developed and validated a microarray derived entirely from $N$. benthamiana EST sequences (the Nb-array). The current array is composed of oligonucleotide probes (60-mers) corresponding to 13,014 unique $N$. benthamiana EST. In order to provide a more stringent test of the hypothesis that RNA viruses, regardless of the host species (plant or animal), regulate a common "core" suite of genes, an additional 401 probes corresponding to plant homologues of genes shown to be differentially expressed in response to animal viruses were included on the array. In order to identify and design probes for these genes, a comprehensive list of host genes that are differentially expressed in response to virus infection was developed from the literature. After filtering the data set to remove genes absent in plant genomes (e.g., immune system-type genes), the list was used to search plant EST databases via BLAST alignments. Selection of sequences to be included on the array was prioritized such that i) they matched $N$. benthamiana sequence, ii) they matched an EST from a dicot species, and iii) they matched an EST from a monocot species. Control experiments demonstrated that there were $N$. benthamiana transcripts that hybridized to the 401 selected probes. Taken together, the Nbarray contains probes for 13,415 transcripts, which corresponds to an estimated coverage of approximately $38 \%$ of the $N$. benthamiana transcriptome. Enquiries regarding these microarrays should be directed to S. Lommel (Table 1).

Transgenic marker lines. The most frequently used transgenic $N$. benthamiana line is $16 \mathrm{c}$ that is homozygous for mGFP5-ER (Siemering et al. 1996), expressing green fluorescent protein (GFP) targeted to the ER (Brigneti et al. 1998; Ruiz et al. 1998). This line has been instrumental in elucidating the mechanism of RNA silencing and for the identification of virus-encoded suppressors of silencing. Seed for the $16 \mathrm{c}$ line are available from the Baulcombe lab.

Primarily to support the study of plant-virus interactions, M. Goodin and colleagues have recently generated several additional lines that express GFP or red fluorescent protein (RFP) fusions targeted to a variety of cellular loci, including the ER, nucleus, nucleolus, actin, and Golgi (Chakrabarty et al. 2007; Goodin et al. 2007b). Seed for these plants can be obtained from the lead author upon written request.

Suspension cell lines. The availability of suspension cell lines, such as the BY-2 line derived from $N$. tabacum cv. Bright Yellow, effectively are the plant equivalent of the human-derived He-La cell line, which facilitates experiments that require synchronous transfection or transformation of cells in culture (Brandizzi et al. 2003; Nagata et al. 1992). Although the utility of the BY-2 cell line is well established, its shortcomings are revealed in cases where certain viruses do not replicate well in tobacco cells or when there is an essential requirement to generate protoplasts from a particular experimental host. For these reasons, Sunter and Bisaro (2003) developed an analogous $N$. benthamiana cell line. The $N$. benthamiana suspension cell line can be obtained from the laboratory of $\mathrm{G}$. Sunter (Table 1).

EST databases. As of October 2007, there was sequence information for 42,566 N. benthamiana EST in GenBank. Of these, approximately 18,000 are unique. Three major contributors are responsible for generating this sequence information: i) The Institute for Genomic Research (TIGR), which provides this information through the Solanaceae Genomics Resource as part of the National Science Foundation-funded Potato Functional Genomics Project; ii) the John Innes Center, which has contributed >8,000 EST; and iii) The Tobacco Genome Initiative (Table 1), which has contributed the largest number of $N$. benthamiana EST $(>25,000)$ to date and provides access to both $N$. benthamiana and $N$. tabacum sequence data via a webbased portal that requires an academic transfer agreement for access.

Although the number of $N$. benthamiana EST may be relatively low, the effective number of EST can be greatly expanded due to the high level of sequence homology present among coding sequences of species in the Solanaceae family (Rensink et al. 2005). As of October 2007, there are nearly 700,000 EST sequences of solanaceous species available in public databases. GenBank records include 258,448 EST for Solanum lycopersicum (tomato), 227,375 for $S$. tuberosum (potato), 158,008 for 
N. tabacum (tobacco), 42,566 for $N$. benthamiana, and 14,017 for Petunia hybrida. In addition, there are ongoing genomics projects for at least five other species in the Solanaceae family. Importantly, these EST can be employed across species as demonstrated recently by Dong and associates (2007), who used tomato EST to effectively silence $N$. benthamiana genes via high-throughput VIGS.

VIGS libraries. Advances are being made in the construction and optimization of libraries to be used as sources of 'VIGSready' constructs. Recently, Liu and Page (2008) have described methods for constructing optimal VIGS libraries based on the TRV vector (Liu et al. 2002; Ratcliff et al. 2001). Library construction utilized RNA isolated from roots of $N$. benthamiana plants treated with methyl jasmonate. Synthesis of cDNA was conducted on a solid phase support and then digested with $R s a$ I to yield short cDNA fragments lacking poly(A) tails. The resulting libraries contained 2,948 EST; $30 \%$ of the cDNA inserts were 401 to $500 \mathrm{bp}$ in length and $99.5 \%$ lacked poly(A) tails. The efficiency of constructs derived from the VIGScDNA libraries was tested, in the context of defining plant secondary metabolite biosynthesis, by silencing a nicotine biosynthetic enzyme, putrescine $\mathrm{N}$-methyltransferase ( $N b P M T)$, with 10 different VIGS-NbPMT constructs ranging in length from 122 to $517 \mathrm{bp}$. Leaf nicotine levels were found to be reduced by more than $90 \%$ when $N b P M T$ was silenced with the various constructs. Based upon these and additional experiments, the authors suggested the following design guidelines for constructs in TRV vectors: i) insert lengths should be in the range of approximately 200 to $1,300 \mathrm{bp}$, ii) they should be positioned in the middle of the cDNA, and iii) homopolymeric regions (i.e., poly(A/T) tails) should not be included.

As an alternative to homologous sequences for VIGS, it may often be more convenient to use heterologous gene sequences. Senthil-Kumar and associates (2007) have systematically examined this issue and found that heterologous gene sequences from distantly related plant species can be used to silence their respective orthologs in the VIGS-efficient plant $N$. benthamiana. Interestingly, a correlation was not always found between gene silencing efficiency and percent homology between the heterologous and endogenous gene sequences. The authors concluded that a 21 -nucleotide stretch of $100 \%$ identity between the heterologous and endogenous gene sequences is not absolutely required for gene silencing (Senthil-Kumar et al. 2007).

\section{Required resources.}

Technologies such as EST mining, RNA profiling, and VIGS have enabled many novel findings but they cannot readily reveal such subtle changes as the relocalization of host proteins that takes place in virus-infected cells (Burch-Smith et al. 2007; Chakrabarty et al. 2007; Goodin et al. 2007a and b), or the recruitment of host factors to sites of virus replication (Serva and Nagy 2006). For this aim, high-throughput localization of the $N$. benthamiana proteome in both the presence and absence of pathogens is required. However, there is presently an under-representation of cDNA libraries for $N$. benthamiana and, particularly, validated full-length cDNA clones for genes from any species in the Solanaceae family to facilitate such studies. For proteins that are highly conserved, it is possible to utilize functionally equivalent Arabidopsis proteins to probe plant-virus interactions (Chakrabarty et al. 2007). Such ORFeome-scale localization is required if the systems biology of plant-pathogen interactions is ever to be fully realized (Meganson and Fraser 2007).

\section{Future prospects.}

$N$. benthamiana is the most widely used experimental host in plant virology. In addition to viruses, this species has been used in the study of a wide variety of plant pathogens (Fig. 6). Importantly, $N$. benthamiana EST are generally highly homologous to those of agriculturally relevant Solanaceous crops, such as tomato, potato, pepper, and petunia, which collectively had a 2006 farm-gate value of US\$5.4 billion in the United States alone (National Agricultural Statistics Service). Thus, functional genomics projects concerned with host-pathogen interactions conducted in $N$. benthamiana will most likely reveal a cadre of genes that play similar roles in agronomically important crops. This point is well supported by the recent work of Dong and associates (2007), who showed that tomato EST, using a high-throughput VIGS approach, can effectively knock down gene expression in $N$. benthamiana. Moreover, the ease of transformation, transient protein expression, and gene-silencing systems for $N$. benthamiana makes this species an extremely attractive model for plant cell biology in general. This is helping to advance many research interests that were initiated in Arabidopsis but which ultimately required support from model systems better suited to facile protein expression methods and microscopy techniques (Bernal et al. 2007; Bracha-Drori et al. 2004; Zhao et al. 2006).

Clearly, $N$. benthamiana's large haploid genome, like that of its more popular relatives, may restrict its use as a genetics system (Fig. 6) (Bennett and Leitch 2005; Bennett et al. 2003). However, given its many other positive attributes, this limitation should in no way be used as a rationale to restrict the development of genomic resources for $N$. benthamiana. One area in need of immediate improvement relates to the transformation and regeneration efficiency of this plant, which is low relative to systems such as Arabidopsis. Currently, there is no comparable floral-dip transformation system for $N$. benthamiana, a technique that has greatly reduced the cost and tedium associated with making transgenic Arabidopsis plants (Clough and Bent 1998). However, as for other plant systems, the efficiency of generating transgenic $N$. benthamiana plants using traditional tissue culture methods will likely be increased as it gains in popularity as a research model.

Another area of concern when using $N$. benthamiana may be the 'overexpression artifacts' that could potentially arise from the use of agroinfiltration. A frequently raised objection is that so-called pathogen-associated molecular patterns (PAMPs) (Ma and Berkowitz 2007) or microbe-associated molecular patterns (MAMPs) (deWit 2007) in Agrobacterium proteins may result in mislocalization of proteins expressed by agroinfiltration. Indeed, PAMPS appear to be critical for TDNA transfer and Agrobacterium-mediated transformation per se and do, indeed, result in relocalization of host proteins, such as VIP1, upon infection (Dafny-Yelin et al. 2008; Zipfel 2008; Zipfel and Felix 2005). However, it stands to reason that the vast majority of proteins expressed by agroinfiltration will not play roles in any such processes. In fact, Agrobacterium-mediated localization of Arabidopsis proteins has proven to be hugely successful (Koroleva et al. 2005; Ohad et al. 2007; Pendle et al. 2005). Additionally, in our experiences with targeting a variety of proteins to subcellular locales including the nucleus, nuclear envelope, nucleolus, ER, chloroplasts, and mitochondria, AFP fusions were correctly targeted in all cases (Goodin et al. 2007b) (unpublished data). Although PAMPs and MAMPs may, in rare cases, interfere with protein localization, there is little indication that this is a general or widespread problem, as indicated by the large body of literature in which the genus Agrobacterium was used to study protein localization in plant cells.

On the other hand, users of agroinfiltration must be aware of the potential for localization artifacts due to overexpression of proteins. Common artifacts include protein aggregation or membrane proliferation, which have been observed occasion- 


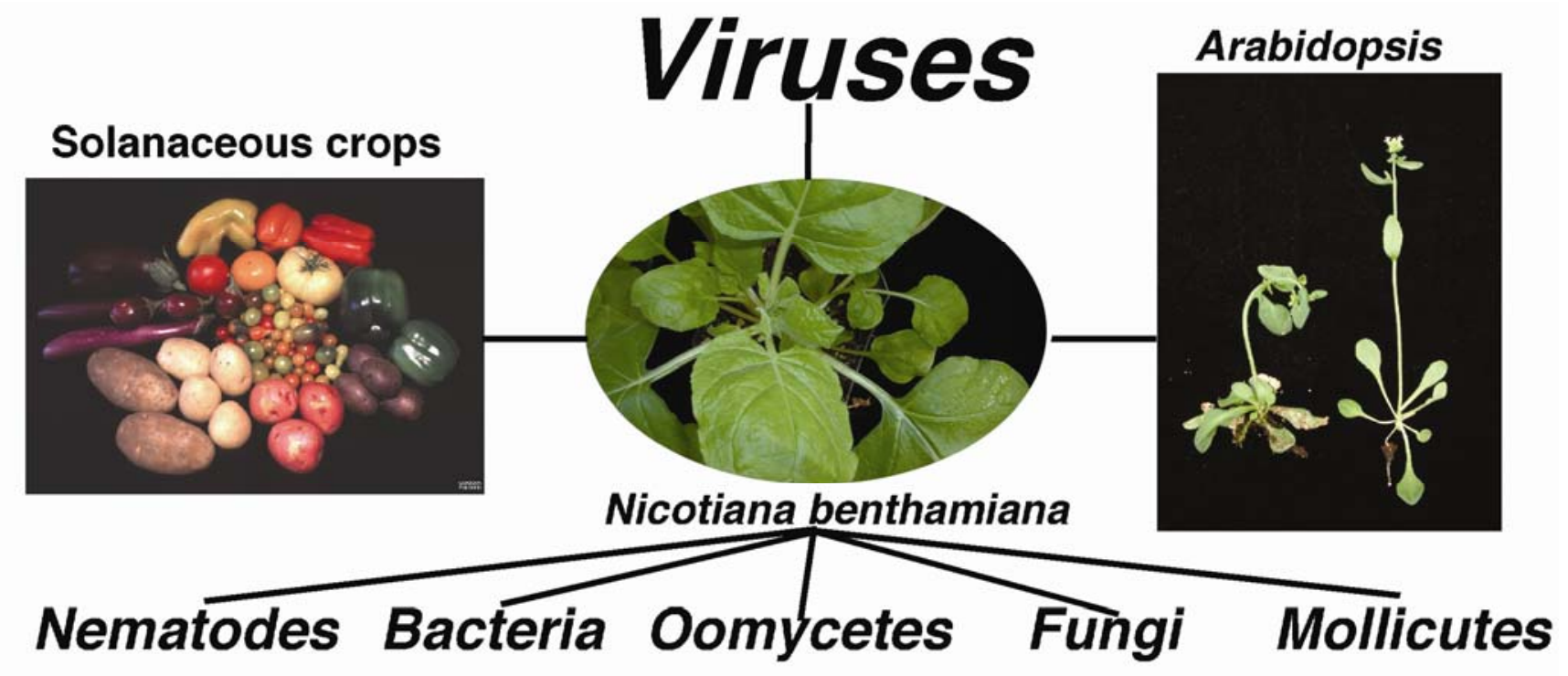

\begin{tabular}{ccccl}
\hline Plant & Ploidy & $\begin{array}{c}\text { Chromosomes } \\
(\mathbf{1 n})\end{array}$ & $\begin{array}{c}\text { Genome size } \\
\mathbf{( M b )}\end{array}$ & $\begin{array}{c}\text { Gene number } \\
\text { (estimated) }\end{array}$ \\
Solanum lycopersicum (tomato) & diploid & 12 & 980 & $33,000-36,000$ \\
S. melongena (eggplant) & diploid & 12 & 1160 & N.D. \\
Capsicum annuum (pepper) & diploid & 12 & 3,700 & N.D. \\
Petunia hybrida (petunia) & diploid & 7 & 1,440 & N.D. \\
S. tuberosum (potato) & diploid & 12 & 870 & N.D. \\
S. tuberosum (potato) & tetraploid & 24 & 1,740 & N.D. \\
Nicotiana tabacum (tobacco) & allopolyploid & 24 & 5,640 & $33,000-36,000$ \\
N. benthamiana & allopolyploid & $\mathbf{1 9}$ & $\mathbf{3 , 1 0 0}$ & N.D. \\
Arabidopsis thaliana & diploid & $\mathbf{5}$ & $\mathbf{1 5 7}$ & $\mathbf{2 6 , 5 0 0}$
\end{tabular}

Fig. 6. Nicotiana benthamiana is the most versatile experimental host for plant viruses and a diverse range of other plant pathogens. Given the high degree of conservation of coding sequences within the family Solanaceae, $N$. benthamiana can support functional genomics projects related to many agriculturally important crops. Finally, $N$. benthamiana is playing a major role in advancing cell biology and biochemical research extending from studies initiated in Arabidopsis thaliana, shown here infected with Impatiens necrotic spot virus (left) or mock inoculated (right). The table compares the characteristics of the genomes for a number of Solanaceous species and Arabidopsis (data reproduced here from the SOL Genomics Network and the Angiosperm DNA C-values database).

ally with integral membrane proteins (M. M. Goodin, unpublished). These and other technical factors that need to be considered prior to embarking on protein localization studies have been addressed by Goodin and associates (2007b).

However, when proteome-scale localization is required (Laketa et al. 2007; Pepperkok and Ellenberg 2006; Simpson and Pepperkok 2006), overexpression vectors are essential for "first pass" classification of proteins with respect to subcellular localization. Proteins of interest to particular laboratories can then be studied with alternate methods of analyses which, in the case of plants, may require the generation of a series of transgenic lines expressing autofluorescent protein fusions under the control of native promoters as a means to most accurately define localization and tissue specificity (Tian et al. 2004). Additionally, expression vectors that utilize promoters other than the Cauliflower mosaic virus $35 \mathrm{~S}$ are available (Chung et al. 2005). A systematic comparison of protein expression via transient or transgenic means using a variety of binary vector derivatives that use promoters other than the ubiquitous $35 \mathrm{~S}$ would be of tremendous value to the field. However, the current approach is for high-throughput localizations of many proteins at a minimal cost per localized protein. This ensures reliance on the $35 \mathrm{~S}$ promoter, which is by far the most convenient to use.
In conclusion, there is a rapidly increasing body of literature that supports the need to develop additional genomics tools for $N$. benthamiana in order to further advance, primarily in plant virology, innate immunity and host-pathogen interactions. However, it is abundantly clear that $N$. benthamiana is poised to provide essential support in plant systems biology in the post-genomics era (Caplan et al. 2008; Chisholm et al. 2006; Mestre and Baulcombe 2006; Takahashi et al. 2007; Tameling and Baulcombe 2007).

\section{ACKNOWLEDGMENTS}

The authors wish to express their sincere gratitude to all who have contributed to this work by responding to our survey or providing $N$. benthamiana seed. We are particularly indebted to D. Baulcombe, S. DineshKumar, F. Garcia-Arenal, J. Moyer, R. Nelson, K. Perry, and N. Robertson for contributing resources and data relevant to this article. We apologize to all colleagues whose research is not mentioned here due to space limitations. Special thanks goes to M. Chase, Royal Botanic Gardens, Kew, for his assistance in obtaining the digital image of the type specimen of $N$. benthamiana. We thank R. Dietzgen for reviewing the manuscript prior to submission. The article is approved as PPNS no. 0475, Department of Plant Pathology, College of Agricultural, Human, and Natural Resource Sciences Agricultural Research Center Project No. WNPO 0616, Washington State University, Pullman 99164-6240, U.S.A. Research on TSWV was funded by the Integrated Pest Management Collaborative Research 
Support Program (award no. EPP-A-00-04-00016-00 to R. A. Naidu). Additional sources of funding include NIH, USDA, and KTRDC grants to M. Goodin and continued KTRDC research funding to D. Zaitlin.

\section{LITERATURE CITED}

Battye, J. S. 1924. Western Australia: A History from its Discovery to the Inauguration of the Commonwealth. Clarendon Press, Oxford.

Bennett, M. D., and Leitch, I. J. 1995. Nuclear DNA amounts in angiosperms. Ann. Bot. 76:113-176.

Bennett, M. D., and Leitch, I. J. 2005. Nuclear DNA amounts in angiosperms - progress, problems and prospects. Ann. Bot. 95:45-90.

Bennett, M. D., Leitch, I. J., Price, H. J., and Johnston, J. S. 2003. Comparisons with Caenorhabditis $(\sim 100 \mathrm{Mb})$ and Drosophila $(\sim 175 \mathrm{Mb})$ using flow cytometry show genome size in Arabidopsis to be $\sim 157 \mathrm{Mb}$ and thus $\sim 25 \%$ larger than the Arabidopsis Genome Initiative estimate of $\sim 125 \mathrm{Mb}$. Ann. Bot. 91:547-557.

Bentham, G. 1869. Pages 469-470 in: Flora Australiensis: A Description of the Plants of the Australian Territory, vol. IV, Styidieae to Pedalineae. L. Reeve \& Co., London,

Bernal, A. J., Jensen, J. K., Harholt, J., Sorensen, S., Moller, I., Blaukopf, C., Johansen, B., de Lotto, R., Pauly, M., Scheller, H. V., and Willats, W. G. 2007. Disruption of ATCSLD5 results in reduced growth, reduced xylan and homogalacturonan synthase activity and altered xylan occurrence in Arabidopsis. Plant J. 52:791-802.

Bisaro, D. M. 2006. Silencing suppression by geminivirus proteins. Virology 344:158-168.

Bracha-Drori, K., Shichrur, K., Katz, A., Oliva, M., Angelovici, R., Yalovsky, S., and Ohad, N. 2004. Detection of protein-protein interactions in plants using bimolecular fluorescence complementation. Plant J. 40:419-427.

Brandizzi, F., Irons, S., Kearns, A., and Hawes, C. 2003. BY-2 cells: Culture and transformation for live cell imaging. Chapter 1: Unit 1.7 in: Current Protocols in Cell Biology. Wiley Interscience, New York. Published online.

Briddon, R. W., and Stanley, J. 2006. Subviral agents associated with plant single-stranded DNA viruses. Virology 344:198-210.

Brigneti, G., Voinnet, O., Li, W. X., Ji, L. H., Ding, S.-W., and Baulcombe, D. C. 1998. Viral pathogenicity determinants are suppressors of transgene silencing in N. benthamiana. EMBO (Eur. Mol. Biol. Organ.) J. 17:67396746.

Brown J. W., Shaw P. J., Shaw P., and Marshall D. F. 2005. Arabidopsis nucleolar protein database (AtNoPDB). Nucleic Acids Res. 33 (Suppl. 1):D633-636.

Burbidge, N. T. 1960. The Australian species of Nicotiana L. (Solanaceae). Aust. J. Bot. 8:342-380.

Burch-Smith, T. M., Anderson, J. C., Martin, G. B., and Dinesh-Kumar, S. P. 2004. Applications and advantages of virus-induced gene silencing for gene function studies in plants. Plant J. 39:734-746.

Burch-Smith, T. M., Schiff, M., Liu, Y., and Dinesh-Kumar, S. P. 2006. Efficient virus-induced gene silencing in Arabidopsis. Plant Physiol. 142:21-27.

Burch-Smith, T. M., Schiff, M., Caplan, J. L., Tsao, J., Czymmek, K., and Dinesh-Kumar, S.P. 2007. A novel role for the TIR domain in association with pathogen-derived elicitors. PLoS Biol. 5(3):e68.

Callaway, A., Liu, W., Andrianov, V., Stenzler, L., Zhao, J., Wettlaufer, S., Jayakumar, P., and Howell, S. H. 1996. Characterization of cauliflower mosaic virus (CaMV) resistance in virus-resistant ecotypes of Arabidopsis. Mol. Plant-Microbe Interact. 9:810-818.

Cao, X., Zhou, P., Zhang, X., Zhu, S., Zhong, X., Xiao, Q., Ding, B., and Li, Y. 2005. Identification of an RNA silencing suppressor from a plant double-stranded RNA virus. J. Virol. 79:13018-13027.

Caplan, J. L., Mamillapalli, P., Burch-Smith, T. M., Czymmek, K., and Dinesh-Kumar, S. P. 2008. Chloroplastic protein NRIP1 mediates innate immune receptor recognition of a viral effector. Cell 132:449-462.

Chakrabarty, C., Banerjee, R., Chung, S. M., Farman, M., Citovsky, V., Hogenhout, S. A., Tzfira, T., and Goodin, M. M. 2007. pSITE vectors for stable integration or transient expression of autofluorescent protein fusions in plants: Probing Nicotiana benthamiana-virus interactions. Mol. Plant-Microbe Interact. 20:740-750.

Chapman, S., Kavanagh, T., and Baulcombe, D. 1992. Potato virus X as a vector for gene expression in plants. Plant J. 2:549-557.

Chase, M. W., Knapp, S., Cox, A. V., Clarkson, J. J., Butsko, Y., Joseph, J., Savolainen, V., and Parokonny, A. S. 2003. Molecular systematics, GISH and the origin of hybrid taxa in Nicotiana (Solanaceae). Ann. Bot. 92:107-127.

Chisholm, S. T., Coaker, G., Day, B., and Staskawicz, B. J. 2006. Hostmicrobe interactions: Shaping the evolution of the plant immune response. Cell 124:803-814.
Christie, S. R., and Crawford, W. E. 1978. Plant virus range of Nicotiana benthamiana. Plant Dis. Rep. 62:20-22.

Chung, S. M., Frankman, E. L., and Tzfira, T. 2005. A versatile vector system for multiple gene expression in plants. Trends Plant Sci. 10:357-361.

Citovsky, V., Lee, L. Y., Vyas, S., Glick, E., Chen, M. H., Vainstein, A., Gafni, Y., Gelvin, S. B., and Tzfira, T. 2006. Subcellular localization of interacting proteins by bimolecular fluorescence complementation in planta. J. Mol. Biol. 362:1120-1131.

Clough S. J., and Bent A. F. 1998. Floral dip: A simplified method for Agrobacterium-mediated transformation of Arabidopsis thaliana. Plant J. 16:735-743.

Coutts, R. H., and Buck, K. W. 1985. DNA and RNA polymerase activities of nuclei and hypotonic extracts of nuclei isolated from tomato golden mosaic virus infected tobacco leaves. Nucleic Acids Res. 13:7881-7897.

Cruz, S. S., Chapman, S., Roberts, A. G., Roberts, I. M, Prior, D. A., and Oparka, K. J. 1996. Assembly and movement of a plant virus carrying a green fluorescent protein overcoat. Proc. Natl. Acad. Sci. U.S.A. 93:6286-6290.

Dardick, C. D. 2007. Comparative expression profiling of $N$. benthamiana leaves systemically infected with three fruit tree viruses. Mol. PlantMicrobe Interact. 20:1004-1017.

Deleris, A., Gallego-Bartolome, J., Bao, J., Kasschau, K. D., Carrington, J. C., and Voinnet, O. 2006. Hierarchical action and inhibition of plant Dicer-like proteins in antiviral defense. Science 313:68-71.

De Wit, P. J. 2007. How plants recognize pathogens and defend themselves. Cell Mol. Life Sci. 64:2726-2732.

Ding, S. W., and Voinnet, O. 2007. Antiviral immunity directed by small RNAs. Cell 130:413-426.

Dong, Y., Burch-Smith, T. M., Liu, Y., Mamillapalli, P., and DineshKumar, S. P. 2007. A ligation-independent cloning TRV vector for highthroughput virus induced gene silencing identifies roles for NbMADS41 and -2 in floral development. Plant Physiol. 145:1161-1170.

Dreher T. W., and Miller W. A. 2006. Translational control in positive strand RNA plant viruses. Virology 344:185-197.

Earley, K. W., Haag, J. R., Pontes, O., Opper, K., Juehne, T., Song, K., and Pikaard, C. S. 2006. Gateway-compatible vectors for plant functional genomics and proteomics. Plant J. 45:616-629.

Escobar, N. M., Haupt, S., Thow, G., Boevink, P., Chapman, S., and Oparka, K. 2003. High-throughput viral expression of cDNA-green fluorescent protein fusions reveals novel subcellular addresses and identifies unique proteins that interact with plasmodesmata. Plant Cell 15:1507-1523.

Fu, D. Q., Zhu, B. Z., Zhu, H. L., Jiang, W. B., and Luo, Y. B. 2005. Virusinduced gene silencing in tomato fruit. Plant J. 43:299-308.

Gabriëls, S. H., Vossen, J. H., Ekengren, S. K., van Ooijen, G., Abd-ElHaliem, A. M., van den Berg, G. C., Rainey, D. Y., Martin, G. B., Takken, F. L., de Wit, P. J., and Joosten, M. H. 2007. An NB-LRR protein required for HR signaling mediated by both extra- and intracellular resistance proteins. Plant J. 50:14-28.

Gabriëls, S. H. E. J., Takken, F. L. W., Vossen, J. H. de Jong, C. F., Liu, Q., Turk, S. C., Wachowski, L. K., Peters, J., Witsenboer, H. M., de Wit, P. J., and Joosten, M. H. 2006. cDNA-AFLP, combined with functional analysis reveals novel genes involved in the hypersensitive response. Mol. Plant-Microbe Interact. 19:567-576.

Goodin, M., Yelton, S., Ghosh, D., Mathews, S., and Lesnaw, J. 2005. Live-cell imaging of rhabdovirus-induced morphological changes in plant nuclear membranes. Mol. Plant-Microbe Interact. 18:703-709.

Goodin, M. M., Dietzgen, R. G., Schichnes, D., Ruzin, S., and Jackson, A. O. 2002. pGD vectors: Versatile tools for the expression of green and red fluorescent protein fusions in agroinfiltrated plant leaves. Plant J. 31:375-383.

Goodin, M. M., Chakrabarty, R., Yelton, S., Martin, K., Clark, A., and Brooks, R. 2007a. Membrane and protein dynamics in live plant nuclei infected with Sonchus yellow net virus, a plant-adapted rhabdovirus. J. Gen. Virol. 88:1810-1820.

Goodin, M. M., Chakrabarty, R., Banerjee, R., Yelton, S., and DeBolt, S. 2007b. New Gateways to discovery. Plant Physiol. 145:1100-1109.

Goodspeed, T. H. 1954. Pages 485-487 in: The Genus Nicotiana: Origins, Relationships and Evolution of its Species in the Light of Their Distribution, Morphology and Cytogenetics. Chronica Botanica, Waltham, MA, U.S.A.

Heese, A., Hann, D. R., Gimenez-Ibanez, S., Jones, A. M., He, K., Li, J. Schroeder, J. I., Peck, S. C., and Rathjen, J. P. 2007. The receptor-like kinase SERK3/BAK1 is a central regulator of innate immunity in plants. Proc. Natl. Acad. Sci. U.S.A. 104:12217-12222.

Jaccard, P. 1908. Nouvelles recherches sur la distribution floral. Bull. Soc. Vaudoise Sci. Nat. 44:223-270.

Kamoun, S., Hamada, W., and Huitema, E. 2003. Agrosuppression: A bioassay for the hypersensitive response suited to high-throughput screening. Mol. Plant-Microbe Interact. 16:7-13. 
Kanneganti, T. D., Bai, X., Tsai, C. W., Win, J., Meulia, T., Goodin, M. Kamoun, S., and Hogenhout, S. A. 2007. A functional genetic assay for nuclear trafficking in plants. Plant J. 50:149-158.

Karimi, M., Bleys, A., Vanderhaeghen, R., and Hilson, P. 2007. Building blocks for plant gene assembly. Plant Physiol. 145:1183-1191.

Keevil, J. J. 1949. Benjamin Bynoe, Surgeon of H.M.S. Beagle. J. Hist. Med. IV:90-111.

Knapp, S., Chase, M. W., and Clarkson, J. J. 2004. Nomenclatural changes and a new sectional classification in Nicotiana (Solanaceae). Taxon 53:73-82.

Koroleva, O. A., Tomlinson, M. L., Leader, D., Shaw, P., and Doonan, J. H. 2005. High-throughput protein localization in Arabidopsis using Agrobacterium-mediated transient expression of GFP-ORF fusions. Plant J. 41:162-174.

Kumagai, M. H., Donson, J., della-Cioppa, G., Harvey, D., Hanley, K., and Grill, L. K. 1995. Cytoplasmic inhibition of carotenoid biosynthesis with virus-derived RNA. Proc. Natl. Acad. Sci. U.S.A. 92:1679-1683.

Laketa, V., Simpson, J. C., Bechtel, S., Wiemann, S., and Pepperkok, R. 2007. High-content microscopy identifies new neurite outgrowth regulators. Mol. Biol. Cell 18:242-252.

Lara-Cabrera, S. I., and Spooner, D. M. 2004. Taxonomy of North and Central American diploid wild potato (Solanum sect. Petota) species: AFLP data. Plant Syst. Evol. 248:29-142.

Lindbo, J. A. 2007. TRBO: A high-efficiency Tobacco mosaic virus RNAbased overexpression vector. Plant Physiol. 145:1232-1240.

Liu, E., and Page, J. E. 2008. Optimized cDNA libraries for virus-induced gene silencing (VIGS) using tobacco rattle virus. Plant Methods 4:5.

Liu, Y., Schiff, M., and Dinesh-Kumar, S. P. 2002. Virus-induced gene silencing in tomato. Plant J. 31:777-786.

Lucas, W. J. 2006. Plant viral movement proteins: Agents for cell-to-cell trafficking of viral genomes. Virology 344:169-184.

Ma, W., and Berkowitz, G. A. 2007. The grateful dead: Calcium and cell death in plant innate immunity. Cell Microbiol. 9:2571-2585.

Martin, A., Cabrera y Poch, H. L., Martinez Herrera, D., and Ponz, F. 1999. Resistances to turnip mosaic potyvirus in Arabidopsis thaliana. Mol. Plant-Microbe Interact. 12:1016-1021.

Megason, S. G., and Fraser, S. E. 2007. Imaging in systems biology. Cell 130:784-795.

Messinese, E., Mun, J. H., Yeun, L. H., Jayaraman, D., Rouge, P., Barre, A., Lougnon, G., Schornack, S., Bono, J. J., Cook, D. R., and Ane, J. M. 2007. A novel nuclear protein interacts with the symbiotic DMI3 calcium- and calmodulin-dependent protein kinase of Medicago truncatula. Mol. Plant-Microbe Interact. 20:912-921.

Mestre, P., and Baulcombe, D. C. 2006. Elicitor-mediated oligomerization of the tobacco $\mathrm{N}$ disease resistance protein. Plant Cell 18:491-501.

Moore, S., Payton, P., Wright, M., Tanksley, S., and Giovannoni, J. 2005. Utilization of tomato microarrays for comparative gene expression analysis in the Solanaceae. J. Exp. Bot. 56:2885-2895.

Musiychuk, K., Stephenson, N., Bi, H., Farrance, C. E., Orozovic, G., Brodelius, M., Brodelius, P., Horsey, A., Ugulava, N., Shamloul, A.-M., Mett, V., Rabindran, S., Streatfield, S. J., and Yusibov, V. 2007. A launch vector for the production of vaccine antigens in plants. Influenza 1:1925 .

Nagata, T., Nemoto, Y., and Hasezawa, S. 1992. Tobacco BY-2 cell line as the "HeLa" cell in the cell biology of higher plants. Int. Rev. Cytol. 132:1-30.

Nagy, P. D., and Pogany, J. 2006. Yeast as a model host to dissect functions of viral and host factors in Tombusvirus replication. Virology 344:211-220.

Narayan, R. K. J. 1987. Nuclear DNA changes, genome differentiation and evolution in Nicotiana (Solanaceae). Plant Syst. Evol. 157:161-180.

Ohad, N., Shichrur, K., and Yalovsky, S. 2007. The analysis of proteinprotein interactions in plants by bimolecular fluorescence complementation. Plant Physiol. 145:1090-1099.

Panavas, T., Serviene, E., Pogany, J., and Nagy, P. D. 2008. Genome-wide screens for identification of host factors in viral replication. Methods Mol. Biol. 451:615-624.

Pendle, A. F., Clark, G. P., Boon, R., Lewandowska, D., Lam, Y. W., Andersen, J., Mann, M., Lamond, A. I., Brown, J. W., and Shaw, P. J. 2005. Proteomic analysis of the Arabidopsis nucleolus suggests novel nucleolar functions. Mol. Biol. Cell 16:260-269.

Pepperkok, R., and Ellenberg, J. 2006. High-throughput fluorescence microscopy for systems biology. Nat. Rev. Mol. Cell Biol. 7:690-696.

Popescu, S. C., Popescu, G. V., Bachan, S., Zhang, Z., Seay, M., Gerstein, M., Snyder, M., and Dinesh-Kumar, S. P. 2007. Differential binding of calmodulin-related proteins to their targets revealed through highdensity Arabidopsis protein microarrays. Proc. Natl. Acad. Sci. U.S.A. 104:4730-4735.

Quacquarelli, A. 1975. N. benthamiana Domin as a host for plant viruses. Phytopathol. Mediterr. 14:36-39.
Ratcliff, F., Martin-Hernandez, A. M., and Baulcombe, D. C. 2001 Technical advance. Tobacco rattle virus as a vector for analysis of gene function by silencing. Plant J. 25:237-245.

Rensink, W. A., Lee, Y., Liu, J., Iobst, S., Ouyang, S., and Buell, C. R. 2005. Comparative analyses of six solanaceous transcriptomes reveal a high degree of sequence conservation and species-specific transcripts. BMC Genomics 6:124.

Robertson, D. 2004. VIGS vectors for gene silencing: Many targets, many tools. Annu. Rev. Plant Biol. 55:495-519.

Roth, B. M., Pruss, G. J., and Vance, V. B. 2004. Plant viral suppressors of RNA silencing. Virus Res. 102:97-108.

Ruiz, M. T., Voinnet, O., and Baulcombe, D. C. 1998. Initiation and maintenance of virus-induced gene silencing. Plant Cell 10:937-946.

Ryu, C. M., Anand, A., Kang, L., and Mysore, K. S. 2004. Agrodrench: A novel and effective agroinoculation method for virus-induced gene silencing in roots and diverse Solanaceous species. Plant J. 40:322-331. Corregendum in 2006. Plant J. 45:869.

Schob, H., Kunz, C., and Meins, F., Jr. 1997. Silencing of transgenes introduced into leaves by agroinfiltration: a simple, rapid method for investigating sequence requirements for gene silencing. Mol. Gen. Genet. 256:581-585

Segers, G. C., van Wezel, R., Zhang, X., Hong, Y., and Nuss, D. L. 2006. Hypovirus papain-like protease p29 suppresses RNA silencing in the natural fungal host and in a heterologous plant system. Eukaryot. Cell 5:896-904.

Senthil, G., Liu, H., Puram, V. G., Clark, A., Stromberg, A., and Goodin, M. M. 2005. Specific and common changes in Nicotiana benthamiana gene expression in response to infection by enveloped viruses. J. Gen. Virol. 86:2615-2625.

Senthil-Kumar, M., Hema, R., Anand, A., Kang, L., Udayakumar, M., and Mysore, K. S. 2007. A systematic study to determine the extent of gene silencing in Nicotiana benthamiana and other Solanaceae species when heterologous gene sequences are used for virus-induced gene silencing. New Phytol. 176:782-791.

Serva, S., and Nagy, P. D. 2006. Proteomics analysis of the Tombusvirus replicase: Hsp70 molecular chaperone is associated with the replicase and enhances viral RNA replication. J. Virol. 80:2162-2169.

Siemering, K. R., Golbik, R., Sever, R., and Haseloff, J. 1996. Mutations that suppress the thermosensitivity of green fluorescent protein. Curr. Biol. 6:1653-1663.

Simpson, J. C., and Pepperkok, R. 2006. The subcellular localization of the mammalian proteome comes a fraction closer. Genome Biol. 7:222.

Stokes, J. L. 1846. Discoveries in Australia; with an Account of the Coasts and Rivers Explored and Surveyed During the Voyage of H. M. S. Beagle, in the Years 1837-38-39-40-41-42-43, Volumes I \& II. T. and W. Boone, London.

Strasser, R., Bondili, J. S., Schoberer, J., Svoboda, B., Liebminger, E., Glossl, J., Altmann, F., Steinkellner, H., and Mach, L. 2007. Enzymatic properties and subcellular localization of Arabidopsis beta-N-acetylhexosaminidases. Plant Physiol. 145:5-16.

Sunter, G., and Bisaro, D. M. 2003. Identification of a minimal sequence required for activation of the Tomato golden mosaic virus coat protein promoter in protoplasts. Virology 305:452-462.

Takahashi, Y., Nasir, K. H., Ito, A., Kanzaki, H., Matsumura, H., Saitoh, H., Fujisawa, S., Kamoun, S., and Terauchi, R. 2007. A high-throughput screen of cell-death-inducing factors in Nicotiana benthamianaidentifies a novel MAPKK that mediates INF1-induced cell death signaling and non-host resistance to Pseudomonas cichorii. Plant J. 49:10301040 .

Tameling, W. I., and Baulcombe, D. C. 2007. Physical association of the NB-LRR resistance protein Rx with a Ran GTPase-activating protein is required for extreme resistance to Potato virus X. Plant Cell 19:16821694

Tardif, G., Kane, N. A., Adam, H., Labrie, L., Major, G., Gulick, P., Sarhan, F., and Laliberte, J. F. 2007. Interaction network of proteins associated with abiotic stress response and development in wheat. Plant Mol. Biol. 63:703-718.

Thomas, C. L, Jones, L., Baulcombe, D. C., and Maule, A. J. 2001. Size constraints for targeting post-transcriptional gene silencing and for RNA-directed methylation in $N$. benthamiana using a Potato virus $X$ vector. Plant J. 25:417-425.

Thomas, C. L., Bayer, E. M., Ritzenthaler, C., Fernandez-Calvino, L., and Maule, A. J. 2008. Specific targeting of a plasmodesmal protein affecting cell-to-cell communication. PLoS Biol. 6:e7.

Tian, G. W., Mohanty, A., Chary, S. N., Li, S., Paap, B., Drakakaki, G., Kopec, C. D., Li, J., Ehrhardt, D., Jackson, D., Rhee, S. Y, Raikhel, N. V., and Citovsky, V. 2004. High-throughput fluorescent tagging of fulllength Arabidopsis gene products in planta. Plant Physiol. 135:25-38.

Voinnet, O., Rivas, S., Mestre, P., and Baulcombe, D. 2003. An enhanced transient expression system in plants based on suppression of gene si- 
lencing by the p19 protein of Tomato bushy stunt virus. Plant J. 33:949956.

Wang, R. Y., and Nagy, P. D. 2008. Tomato bushy stunt virus co-opts the RNA-binding function of a host metabolic enzyme for viral genomic RNA synthesis. Cell Host Microbe. 3:178-187.

Xiao, F., Giavalisco, P., and Martin, G. B. 2007. Pseudomonas syringae type III effector AvrPtoB is phosphorylated in plant cells on serine 258, promoting its virulence activity. J. Biol. Chem. 282:30737-30744.

Yang, S., Carter, S. A., Cole, A. B., Cheng, N., and Nelson, R. 2004. A natural variant of a host RNA-dependent RNA polymerase is associated with increased susceptibility to viruses by Nicotiana benthamiana. Proc. Natl. Acad. Sci. U.S.A. 101:6297-6302.

Zhao, Q., Leung, S., Corbett, A. H., and Meier, I. 2006. Identification and characterization of the Arabidopsis orthologs of nuclear transport factor 2, the nuclear import factor of ran. Plant Physiol. 140:869-878.
Zipfel, C. 2008 Pattern-recognition receptors in plant innate immunity. Curr. Opin. Immunol. 20:10-16.

Zipfel, C., and Felix, G. 2005. Plants and animals: A different taste for microbes? Curr. Opin. Plant Biol. 8:353-360.

\section{AUTHOR-RECOMMENDED INTERNET RESOURCES}

Australia's Virtual Herbarium website: www.rbg.vic.gov.au/avh AusPGRIS database: www2.dpi.qld.gov.au/extra/asp/auspgris National Agricultural Statistics Service website: www.nass.usda.gov Royal Botanic Gardens, Kew Angiosperm DNA C-values database: data.kew.org/cvalues/database1.html

Sol genomics network: www.sgn.cornell.edu

TIGR Solanaceae Genomics Resource website: www.tigr.org/tdb/sol 